Cultural Education An International Perspective. December 2000 // INCA (International Review of Curriculum and Assessment Frameworks Internet Archive). London: INCA, QCA, nfer, 2000. -58 p.

УДК 378.14

Юлія Мельничук

\title{
ФОРМУВАННЯ ГОТОВНОСТІ МАЙБУТНІХ УЧИТЕЛІВ ПОЧАТКОВИХ КЛАСІВ ДО ОРГАНІЗАЦІЇ СПІЛКУВАННЯ УЧНІВ
}

Мельничук Ю. Ю. Формування готовності майбутніх учителів початкових класів до організації спілкування учнів.

У статті на основі вивчення теоретичних праць, присвячених проблемі професійнопедагогічної підготовки майбутніх учителів початкових класів, розкрито різні підходи до ії трактування, визначено змістові компоненти та 3'ясовано сутність готовності студентів до організації спілкування молодших школярів у процесі навчання.

Ключові слова: підготовка майбутніх учителів початкових класів, організація спілкування, готовність до педагогічної діяльності, вольові якості, комунікативні уміння.

Мельничук Ю. Ю. Формирование готовности будущих учителей начальных классов к организации общения учащихся.

В статье на основе изучения теоретических работ, посвященных проблеме профессионально-педагогической подготовки будущих учителей начальных классов, раскрыты различные подходы к ее трактовке, определены содержательные компоненты и описана сущность готовности студентов к организации общения младших школьников в процессе обучения.

Ключевые слова: подготовка будущих учителей начальных классов, организация общения, готовность к педагогической деятельности, волевые качества, коммуникативные умения.

Melnychuk $\mathrm{Yu} . \mathrm{Yu}$. The formation of rediness of future primary school reachers for the organization of pupils' communication.

In the article based on the study of theoretical works on the problem of professional and pedagogical training of future primary school teachers, various approaches to its understanding are shown, substantial components are defined and the essence of readiness of students for the organization of junior schoolchildren communication in the process of training is described.

Key words: future primary school reachers training, organization of communication, readiness for pedagogical activity, volitional powers, communication skills.

Проблема підготовки вчителя початкових класів до організації спілкування молодших школярів є частиною загальної проблеми підготовки вчителя у системі вищої педагогічної освіти.

Аналіз психолого-педагогічної літератури показав, що удосконалення підготовки вчителів до навчально-виховної роботи залишається актуальною проблемою сучасної педагогічної освіти (О. Абдуліна, С. Архангельський, Є. Белозерцев, В. Сластьонін, Л. Спірін, Г. Троцко та ін.).

У педагогіці та психології вищої школи інтенсивно розробляються проблеми 
професійної підготовки майбутнього вчителя початкових класів, накопичений багатий досвід підготовки студентів до навчально-виховної роботи у початковій школі (О. Боданська, М. Волошина, Н. Гурець, О. Кіліченко, Д. Мазоха, Є. Мількова, С. Соломаха, Н. Сулаєва, I. Трубавіна, Л. Хомич та ін.) але у структурі підготовки майбутнього вчителя майже не відображається організація спілкування молодших школярів.

Сучасні вимоги до навчально-виховного процесу, специфіка роботи й аналіз досвіду вчителів початкових класів показують, що недостатньо розроблена методика забезпечення готовності учителів початкових класів до організації спілкування учнів призводить до формалізму у процесі формування комунікативних умінь учнів, неглибокому розумінню цілей навчання учителями.

Отже, метою статmі є визначення змісту та сутності готовності студентів до організації спілкування молодших школярів у процесі навчання.

Проблема готовності студентів до педагогічної праці набула широкого висвітлення в роботах педагогів і психологів. Психологічний аспект цієї проблеми знайшов відображення в дослідженнях Л. Ахтарієвої, М. Дьяченко, М. Левченко, Л. Разборової та інших. Педагогічний аспект було висвітлено в роботах Ю. Бабанського, Ю. Васильєва, Л. Кондрашової, Н. Кузьміної, В. Сластьоніна, О. Щербакова, М. Вієвської, Л. Нечаєвої та інших.

Так, В. Сластьонін розглядає готовність як «особливий психічний стан, який передбачає здатність ідентифікувати себе з іншими, або перцептивну здатність, психічний стан, що відображає динамізм особистості, багатство іiї внутрішньої енергії, ініціативність, винахідливість», тощо [5, с. 79]. Окрім цього В. Сластьонін до змісту поняття «готовність» відносить емоційну стійкість, що забезпечує витримку, професійно-педагогічне мислення, тобто таке, яке забезпечує проникнення у причинно-наслідкові зв'язки педагогічного процесу, допомагає аналізувати свою діяльність, відшукувати наукове обгрунтування успіхів та невдач, передбачати результати роботи.

Л. Кондрашова, аналізуючи різні підходи до визначення готовності, говорить про необхідність комплексного підходу до професійної підготовки студентів педагогічних ВНЗ, сутність якого вчена вбачає у єдності загальнопсихологічного та морального розвитку спеціаліста, необхідності формування моральної та психологічної сфер особистості майбутнього вчителя [2].

Змістовний аспект готовності майбутніх учителів до педагогічної праці був у центрі уваги багатьох дослідників, серед яких М. Дьяченко та Л. Кандибович. Ці науковці розглядають готовність із психологічних позицій і у структурі виокремили мотиваційний, орієнтаційний, операційний, оціночний та вольовий компоненти.

Заслуговує на увагу дослідження О. Мороза, де «готовність» трактується як «підготовленість» та виокремлюються такі структурні компоненти: а) психологічна готовність; б) теоретична підготовленість; в) практична готовність до професії вчителя; г) ідейно-політична підготовка, світогляд та загальна культура вчителя; д) професійнопедагогічна спрямованість особистості вчителя [3, с. 71-75].

Представлені підходи до трактування змісту готовності студентів педагогічного ВН3 до професійної діяльності мають один спільний недолік, а саме- відсутність такого важливого компонента, як комунікативний. Звертання до комунікативного компонента у трактуванні «готовності до шкільного навчання» [4, с. 395] має місце в доробку О. Савченко. Ми поділяємо цю точку зору, тому що, як свідчать проаналізовані педагогічні праці, аналіз причин формалізму в навчально-виховному процесі, пасивності й досить низької 
самостійності учнів треба шукати в невмінні вчителя ставити та розв'язувати комунікативні задачі; в його непідготовленості до здійснення комунікативної функції в педагогічному процесі. «Ліквідація такого положення можлива, якщо виробити в майбутнього вчителя початкових класів уміння формулювати комунікативне завдання» [1, с. 43].

Сучасний формалізм навчально-виховного процесу здебільшого пояснюється тим, що вчителі початкових класів інколи нечітко уявляють собі структуру навчання і відповідно зводять до мінімуму активність учнів; відкидають такий важливий та ефективний компонент навчально-виховного процесу як спілкування між однолітками. Як ми уже зазначали, вихід із такої ситуації - у здійсненні спеціально-спрямованої підготовки студентів до такого роду занять.

Виходячи 3 вищезазначеного, уважаємо, що готовність майбутніх учителів початкових класів характеризується сукупністю певних якостей особистостей студентів та забезпечує можливість і доцільність організації спілкування учнів. Також для нас важливі висновки М. Вієвської. [1] та Л. Кондрашової [2], які уважають, що студентам педагогічного ВНЗ важливо оволодіти теоретичними основами спілкування, здобути комунікативні вміння на практиці, розвивати комунікативні здібності, зокрема, це характерно для майбутніх учителів початкових класів.

Розкриваючи цей елемент змісту готовності майбутніх учителів початкових класів до організації спілкування учнів, виокремлюємо такі компоненти цієї готовності:
а) мотиваційний;
б) когнітивний;
в) операційний;
г) вольовий;
д) комунікативний.

Основу мотиваційного компонента складає професійно-педагогічна спрямованість на організацію спілкування. Показниками професійно-педагогічної спрямованості, за М. Вієвською, можна уважати: особисте бажання майбутніх учителів початкових класів застосовувати свої знання, здібності, досвід у безпосередньому обміні інформацією, думками, тобто у спілкуванні [1]. Професійна спрямованість на організацію спілкування - це позитивне ставлення до суб'єкт-суб' єктного спілкування, прагнення вдосконалювати свою підготовку та педагогічну майстерність щодо цього виду роботи.

Позитивні зміни у змісті професійної спрямованості на організацію спілкування проявляються в тому, що «міцніють мотиви спілкування учнів, а в цілому міцніє прагнення будувати свої взаємовідносини з учнями на засадах співробітництва, бачити особистість у кожній дитині» [1, с. 49].

Якщо враховувати, що інтерес до спілкування виражається у концентруванні думок майбутнього вчителя початкових класів на самому процесі спілкування, то ступінь його сформованості визначає й характер роботи майбутнього спеціаліста над собою.

«Мотиваційний компонент готовності майбутніх учителів початкових класів до організації спілкування учнів складає основу для реалізації інших ï структурних компонентів, тобто є результатом сформованості певних якостей особистості, є внутрішньою умовою iii подальшого вдосконалення, стимулює ціннісні орієнтації, інтелектуальні й емоційно-вольові процеси та забезпечує сталість професійних поглядів» [1, с. 49].

Для успішної організації та керування спілкуванням молодших школярів майбутньому вчителю важливо знати не лише способи організації, умови керування та прийоми створення мовленнєвої ситуації. Учитель у процесі своєї педагогічної діяльності 
спрямовує свою увагу й зусилля на ті дії, що повинен виконувати сам, на ті теоретичні знання та практичні вміння й навички, якими має володіти. Одночасно в полі зору вчителя постійно знаходиться колектив учнів, на роботу з яким і спрямовані увага, зусилля, знання, вміння та навички щодо організації спілкування. Організація спілкування між самими учнями неможлива без знання вчителем теоретичних засад спілкування, специфіки спілкування молодших школярів, володіння методикою розвитку мовлення, що складають зміст когнітивного та операційного компонентів.

Успіх учителя початкових класів залежить від того, чи зможе він залучити молодших школярів до спільної колективної діяльності - суб'єкт-суб'єктне спілкування, допомогти кожному визначити свою роль у цьому процесі, згідно зі своїми здібностями, інтересами. Ці зусилля вчителя будуть реалізовані тоді, коли кожний учень початкової школи буде перебувати в активній мовленєвій позиції, самостійно забажає перейти із загону слухачів до загону «ораторів».

Організація вчителем спілкування учнів вимагає від педагога інтуїтивного відчуття учня, уміння співпереживати, використовувати емоційні почуття для створення позитивного, доброзичливого спілкування, яке б сприяло відвертому та відкритому обмінові думками, почуттями, досвідом. Завдання майбутнього вчителя полягає й у тому, щоб бути справжнім диригентом на уроці та в позаурочний час, організатором цікавого, пізнавального спілкування завдяки власному прикладу. Саме на цьому етапі важливі взаємовідносини «вчитель-учень», де виникає постійна можливість для вчителя демонструвати наочні прийоми, способи спілкування, урахування інтересів співбесідників, настроїв, вікових особливостей інших індивідуальних якостей.

Організація спілкування між учителем та учнем на принципах співробітництва передбачає також високий рівень вольових якостей майбутнього вчителя.

Сформованість комунікативного компоненту готовності студентів до організації спілкування учнів значною мірою залежить від характеру спілкування молодших школярів у ході ігрової діяльності. Це передбачає оволодіння майбутнім учителем початкових класів уміннями створювати та розв'язувати комунікативні завдання - тобто систему конкретних дій, за допомогою яких учитель створює умови для активної спільної діяльності та спілкування педагога та школярів, школярів між собою, що забезпечує результативність педагогічних завдань. Майбутніх учителів початкових класів необхідно навчати цьому обов'язково у стінах педвузу, бо вміння ставити учня в позицію активного учасника процесу навчання, позицію співбесідника виникає тільки в результаті наполегливого виконання вправ, тренінгів, участі в рольових іграх серед самих студентів під час аудиторного навчання.

Отже, постає проблема визначення комунікативних умінь, необхідних майбутньому вчителю початкових класів для організації спілкування учнів.

Спираючись на загальні комунікативні уміння педагогічного спілкування, а також використовуючи результати експертних оцінок викладачів вищих навчальних педагогічних закладів, учителів початкових класів, студентів, було визначено такі комунікативні вміння:

- розуміти, а не тільки бачити, тобто адекватно моделювати особистість молодшого школяра;

- керувати своєю поведінкою, настроєм під час безпосереднього спілкування з учнями та спостереженням за спілкуванням самих учнів;

- «подати себе» у процесі спілкування з учнями, створювати наочний приклад для копіювання стилю, темпу, емоційності, образності, яскравості під час спілкування; 
- бути уважним слухачем;

- вербальної та невербальної взаємодії з молодшими школярами;

- усвідомлювати, систематизувати, переносити інформацію, отриману в процесі спілкування;

- усвідомлювати мету спілкування, пошук способів його організації в різних видах діяльності;

- організовувати спонтанне спілкування учнів;

- усвідомлювати мотиви вибору та способу організації спілкування учнів.

Визначення можливості й необхідності організації спілкування молодших школярів потребує спеціальної професійної підготовки майбутніх учителів. Результат такої підготовки студентів визначається рівнем готовності майбутніх учителів початкових класів до організації спілкування учнів. Перспективою спеціального дослідження вважаємо розгляд питання підготовки майбутніх учителів початкових класів до організації спілкування учнів в умовах виховної роботи.

\section{Література}

1. Виевская М. Г. Формирование готовности будущего учителя к педагогическому взаимодействию с учащимися: дисс. ... канд. пед. наук: 13.00.01./ Виевская Муза Георгиевна. - Кривой Рог, 1994. - 165 с. 2. Кондрашова Л. В. Методика подготовки будущего учителя к педагогическому взаимодействию с учащимися / Л.В.Кондрашова. Москва : Прометей, 1990. - 160 с. 3. Мороз А. Г. Формирование готовности к педагогической деятельности молодых учителей / А. Г. Мороз // Психолого-педагогические основы совершенствования подготовки специалистов в университете. - Днепропетровск, 1980. - С. 71-75. 4. Савченко О. Я. Дидактика початкової школи: [підручник для студентів педагогічних факультетів] / О. Я. Савченко. - Київ : Абрис, 1997. - 416 с. 5. Сластенин В. А. Профессиональная готовность учителя к воспитательной работе: содержание, структура, функционирование / В. А. Сластенин // Профессиональная підготовка учителя в системе высшего педагогического образования. - Москва : Педагогика, 1982. - 151 с.

Віра Перепьолка

\section{ФОРМУВАННЯ ПРОФЕСІЙНОЇ МОВНОКОМУНІКАТИВНОЇ КОМПЕТЕНТНОСТІ МАЙБУТНІХ УЧИТЕЛІВ ПОЧАТКОВИХ КЛАСІВ}

Перепьолка В. I. Формування професійної мовнокомунікативної компетентності майбутніх учителів початкових класів.

У статті розглядається одна із важливих концепцій державної мови - формування професійної мовнокомунікативної компетентності майбутніх учителів початкової школи, аналізуються технології іï реалізації. Це формування значною мірою залежить не від отриманих знань, а від деяких додаткових якостей, для позначення яких і використовуються поняття «компетенція» i «компетентність», що найповніше відповідають сучасному розумінню мети освіти.

Ключові слова: компетентність, професійна компетенція, мовнокомунікативна компетентність, педагогічні технології, комунікативна ситуація, мовний і мовленнєвий аспекти, культура мовлення.

Перепьолка В. И. Формирование профессиональной речевой компетентности 